\title{
The Transition to Multiparty Democracy in Tanzania: Some History and Missed Opportunities
}

\author{
By K. I. Tambila
}

\section{Introduction}

Tanzania is cautiously moving towards multi-partyism, a process which will have to involve both destruction and creation: destruction and change of institutions, laws, habits, and psychological blocks which have been created in some cases in more or less the past three hundred years and in others in the past thirty years of independence; creation will mean promulgating new laws, bringing new institutions (like parties) into being, creating new attitudes, and reshaping the minds of both old and young people. After almost thirty years of one party rule, the body politic had become calcified as it were and everything from values, the way of thinking and behavior to institutional set-ups had been distorted or hadened. Hence the need for a transition period which is clearly defined.

Tanzania is not going through this process alone. She is part of a global movement to multipartism which has swept through Eastern Europe, South-East Asia, Africa and Latin America. She is part of a process of people wanting change, control over their lives and their destinies. She is in short part of a process of people crying out for democracy.

In many parts of the world, especially in the Balkans and the former USSR, the movement has opened a pandora's box of both ethnic rivalries and desires to overthrow domination which have led to a lot of bloodshed. These are developments which have not escaped the attention of the broad masses of the people of Tanzania and elicited out of them a certain amount of caution and even fear regarding change.

\section{History of Multipartyism in Tanzania}

In February 1991, the President of Tanzania set up a twenty two man commission to collect views of Tanzanians regarding which political system they wanted and to make recommendations therefrom. The Report of this Presidential Commission, in its attempt to position the changes which are taking place in Tanzania, went into the pre- and post- 
independence political history of this country. ${ }^{1}$ It looked at political parties and civil organisations, especially cooperatives and trade unions, which together went a long way in creating a very lively political atmosphere both in Zanzibar and Tanganyika, albeit one full of glaring short-comings, injustices and restrictions.

It is important to remember that Tanzania is moving into multipartism not from an absolute tabula rasa, but from a short-lived experience of multipartyism. It should be interesting to closely examine who closed this chapter in Tanzania's history and which lessons can be learnt from this experience. Questions arise such as what led to the establishment of the one-party state and which rationalisations were used in justifying its coming into existence.

\section{Independence and after}

Independence was granted to Tanganyika on December 1, 1961 and to Zanzibar initially on a very faulty and unjust Lancaster House arrangement in 1963 followed by a revolution on January 12, 1964. The independence movement began in the mid 1950's, spearheaded by the nationalist movement know as the Tanganyika African National Union (TANU) which was founded in 1954. Its president was a school teacher called Julius Nyerere. Many of the early leadership were mainstream Tanganyikans of the time: teachers, clerks, trade unionists, cooperative leaders, tailors, carpenters, etc.

TANU leaders linked up with trade unions organised under the umbrella of the Tanganyika Federation of Labour (TFL) and the Cooperative movement which had its strongest rural presence in the Lake Victoria zone (Bukoba, Mwanza and Shinyanga), the Kilimanjaro area (Moshi and Arusha) and the southern zones (Mbinga and Mbeya). This alliance resulted in a formidable movement which was broadly representative of the whole country's majority and made for unity. Thus competing parties remained small and weak.

The demands of TANU were not unlike those of other African nationalist movements: self-rule by the colonised which would enable them to organise the direction, scope and pace of their country's development; democratic institutions which they would man themselves and justice in daily life. They argued that colonialism by its very nature could not provide those.

The transition to independence came rather smoothly for Tanganyika within the context of a broadbased and accepted movement. That after independence, development had to be

1

Tanzania Govt., Tume ya Rais ya Mfuno wa Chama Kimoja au Vyama Vingi vya Siasa Tanzania, 1991, Dar es Salaam (1992), para. 25-126. Henceforth the Nyalali Commission Report. 
worked for was also broadly accepted by the populace. The independence slogans, therefore: "Uhuru na Kazi", "Uhuru na Umoja" and "Uhuru na Maendeleo" (Freedom and Work, Freedom and Unity, Freedom and Development) were pregnant with meaning and easily internalised by most people.

Freedom had to be guarded and defended at all costs because it was the basis of everything. Unity was almost taken for granted because no analysis was made of its base. Nevertheless, it too had to be gaurded and defended. Development which was understood as the expansion of what colonialism had started in terms of a specific type of economy, inf rastructure and social services, was to be pursued at any cost including limitations to freedoms taken as commonplace in industrial democracies.

This is the context in which the very leadership which had been heading the movement for freedom - personal and institutional-, democracy, and self-determination was able to argue for the limitations to, and proscription of the freedoms they had been in the forefront to demand from the colonisers. Trade Union freedom was limited and later abolished, cooperatives were controlled and later abolished, political parties other than the ruling party were legislated out of existence, parliament was muzzled and other civic organisations were intimidated into self-censorship, all within the first five years of independence.

\section{Towards the One Party State}

Cranford Pratt, the first principal of the Dar es Salaam University College, lists five reasons leading to first a tendency towards authoritarianism and later to the one-party state. These, he writes, are:

(i) the authoritarian colonial heritage;

(ii) the fragility of post-colonial democratic institutions;

(iii) the anti-colonialist logic of the anti-colonialist movement which demanded unity;

(iv) the self-interest of the TANU leaders who inherited the colonial state apparatus; and finally:

(v) developmentalism in economic thinking. ${ }^{2}$

These points need expanding in order to leave no ambiguity as to what the situation was and the logic of the time. It is argued firstly that colonialism was not a school in democracy. It was rather a school in its antithesis, a school in authoritarianism since it did not pay attention to cultural hegemony which would have taken into consideration the colonial people's own way of expressing themselves. Post colonial leaders had experienced only 
this authoritarian system and inherited all its instruments. It was very easy for them, nay attractive even, to tend towards authoritarianism and to make ready use of legal instruments in consolidating their power.

Secondly, constitutional democracy was not well established after independence and the rules of the game which were relevant to it were either not universally accepted or even well understood. This follows logically from the first point because, indeed, the colonial regime had done its best to oppose the smooth development of democratic institutions. The inheritance had to be fragile institutions. There may be a parallel there today. One is bound to ask whether the rules of the game in the current transition are known, understood and universally accepted.

Thirdly, the anti-colonialist nationalist movement had been massive and fairly well united under TANU. It is argued in the Nyalali Commission Report that this in a way reflected the low level of social differentiation at that time. ${ }^{3}$ It was therefore very easy to view those who opposed TANU, the anti-colonialist nationalist movement, as having placed themselves outside the ranks of their nation. It was, however, easy to use the same argument to view any opposition to ideas and actions not as criticism, least of all as an element of nationalism. Thinking and acting differently were seen as disloyalty and treachery.

Fourthly, it has been argued that many TANU activists had been semi-employed or unemployed people. They had neither technical nor professional skills. These are the ones who inherited the colonial regime and regular incomes from political office. Loss of of fices for many of them would have meant a return to a peasant or artisanal existence. Therefore, a challenge to them meant a direct challenge to their livelihood. This was difficult for many of them to accept.

Finally, the developmentalist logic put economic development before everything. Developmentalism was an elitist and economistic conception of development. Competitive politics was regarded as being divisive and wasteful; there was need for unity for development. Therefore, according to this view, any action (or even thinking) which stood in the way of development could rightly be suppressed for the 'common good' of development.

All this in a way explains the retention of draconian colonial legislation, the introduction of even more oppressive ones and a ready resort to them. The Preventive Detention Act was introduced immediately after independence in $1962 .{ }^{4}$ Someone could be restricted

4 Preventive Detention Act, 1962, Cap. 490; R. Martin, Personal Freedom and the Law in Tanzania, OUP (1974), pp. 87-89. 
without trial and indefinitely so for a mere belief of what "he intend(ed) to do, or (was) trying to do, or what you believe he had done" ${ }^{\prime 5}$.

The Deportation Ordinance remained on the statute books and the Regions and Regional Commissioners Act (1962) and Area Commissioners Act (1962) were enacted, giving vast powers to the of fice holders concerned to deal summarily with suspects by deporting them or detaining them. ${ }^{6}$ In fact, there came a time when mere political discontent was enough reason to be detained. These laws remain until today.

Pratt points out that as a result of the leadership's resistance to accepting challenge "... the several tiny parties which appeared in 1962 were harassed out of existence, their leaders deported or detained and their right to register and to hold meetings severely restricted" ${ }^{7}$. Whether tiny or not was immaterial indeed: What mattered is that intolerance won the day; no attempt was made to create a new culture of tolerance. On the other hand we should add that tolerance is not a self-imposed attitude; it is won after a struggle or struggles. We would like to note further as very telling that so much repression had to be used to kill "the several tiny parties". If these parties were not socially needed, they would have died a natural death. It is very probable that some had real social bases and would have been real threats to TANU.

The one party state came as a logical follow-up of the hounding of other parties out of existence. Ironically, this was done in the name of democracy. J.K. Nyerere had the following to say to the TANU National Conf erence in 1963:

"Where there is one party, and that party is identified with a nation as a whole, the foundations of democracy are firmer than they can ever be where you have two or more parties, each representing only a section of the community." 8

This conception of politics articulated here by Nyerere was not specific to Tanganyika; it was very current in the world at that time. It reduced politics to organisational forms, whereas politics should be to a large extent a question of how differences are resolved. However, one should not wonder too much because that conception was part of developmentalism which was dominant them.

The story of the establishment of the one party system is well known and covered in the literature. It is important to keep it in mind, however, because the arguments used were

J.K. Nyerere, Freedom and Unity, OUP (1966), pp. 312-313.

Martin (supra note 4), pp. 108-110.

7

Pratt (supra note 2), pp. 187-188.

$8 \quad$ Nyerere (supra note 5), p. 196. 
full of weaknesses, and furthermore the establishment of the one party system was a step towards doing away with parliamentary supremacy.

There is no question that up to 1968 parliament was recognised as being supreme. The former President of Tanganyika and President of TANU drew attention to this fact when he was asking the National Assembly to ratify the Union between Tanganyika and Zanzibar. In his speech to the Assembly on 25th April 1964 he said the following:

"This Parliament is the Supreme Organ of the People of Tanganyika. No important constitutional issues or important matter concerning state agreement or concerning the laws of this country can be finally decided by anyone or any group of persons other than this assembly. All such matters must be brought before this house, and it is entirely at your discretion to approve them or reject them. Today, I am submitting to you for consideration a draft agreement for the Union of Tanganyika and Zanzibar." (emphasis added) ${ }^{9}$

By 1968, the party was supreme at the political level. However, during that year, those who supported parliamentary supremacy within the one party state lost to those who aspired to party supremacy over parliament. In word and action the message was made very clear. For example, the then Parliamentary Secretary in the Office of the Second Vice-President, Mr. Richard Wambura, had the following to say to Members of Parliament who wanted clarity on the issue of the status of parliament:

"Mr. Speaker, I want to make it clear that it is the party which is supreme and all the MPs are expected to work under the leadership and guidance of the party. The party picked you MPs in nomination and the party has the right to discipline you and dictate your tasks. It is high time that the MPs should know where they come from, and it is beyond any doubt that this parliament belongs to TANU." ${ }^{10}$

One the same day, October 1st 1968, Mr. R. M. Kawawa, the Second Vice-President and leader of government business in the House, added, after MPs had posed more queries:

"TANU and ASP are the originators of this state. The two parties are policy makers while the duty of government is to implement policies. We have assisted the government with parliament, law and finance to facilitate such implementation ... We are governed mentally by our colonial past in believing that the government is supreme. The German and British impact is still with us. We need to bring about our mental

Parliamentary Debate (Hansard), 25th April, 1964, col. 1, quoted in P. Msekwa, Towards Party Supremacy, Arusha 1977, p. 22 (emphasis added).

10

Ibid., lst October, 1968, Col. 23. 
revolution to remedy this situation ... In a one-party democracy the party is supreme all the way." 11

Over and above introducing confusion as to what a state is and its origins, one can deduce clearly from this statement that Kawawa, a very senior and authoritative state functionary, was justifying the transfer of colonial authoritarianis to the party which he in the same breath was calling a state party.

The actions alluded to above included the sacking of seven vocal Mps at the NEC meeting in Tanga in the same month, the threat to dissolve the National Assembly in 1973 when the majority opposed the Income Tax Bill ${ }^{12}$ and in 1982 the complete disregard of the National Assembly in announcing new taxes. In a New Year Message over Radio Tanzania Dar es Salaam on 31st December 1982, the then President of the Republic, J. K. Nyerere, said:

"You will already have heard of new taxes which come into force tommorow, the first of January, 1983. These tax measures will be debated in parliament in its next sitting, but in the meantime they have to be paid by everyone." 13

This was a very clear case of legislation by the executive. Laws in Tanzania are made by the National Assembly and the President who together constitute parliament. What was happening in the above example was the usurpation of the duties of one part in the process of law-making by the other in such an important matter as the levying of taxes. But it is important to note that this could happen only within the context of party supremacy which had totally emasculated the National Assembly. Party Supremacy was legalised by Act No. 8 of $1975 .^{14}$ In the process of transition, the issue of Parliamentary supremacy will definitely become an important one to be carefully handled, touching upon the separation of powers which in interconnected checks and balances makes a democracy function.

The dismissal of the seven vocal MPs in October 1968 after Wambura's and Kawawa's clarifications was a clear sign that there was in the National Assembly still some fighting spirit to be found. Parliamentary supremacy still had some defenders. The 1973 saga saw the most vocal M.P. being awarded an ambassadorial post in Moscow, not far from the real proverbial Siberia.

Ibid. Col. 47-48.

12

Ibid.

13

Daily News (Dar es Salaam), 1st January 1983.

14 Act No. 8/1975. 
All in all, two things worked for the executive over these years. One was the social origin of the Members of Parliament which, like that of the TANU functionaries earlier on, was artisanal or peasant at the worst and at best school teaching or state/parastatal functionary petit bourgeois. None of the MPs wanted to be sent packing to their original status. The other was the very authoritarian setup of the one-party parliament. There was no other party to cross over to and, constitutionally, no other party could be formed. Furthermore, inner party dissention leading to the formation of party factions was a weak option because again of the social origin of the MPs.

\section{Movement to Multi-Party Politics: History Repeating Itself?}

The Nyalali Commission deals at length with the genesis of the debate on multi-partyism. ${ }^{15}$ In the report, it is pointed out that change was influenced by forces both external and internal. External influences included firstly the very dramatic changes which took place in Eastern Europe, starting with Gorbachev's perestroika and glasnost which ended in the breakdown of the Soviet Union, the ignominious demise of the Ceaucescu regime in Romania, the tumultuous collapse of the Berlin wall and the SED state in East Germany, and the more ordered changes in Hungary and Bulgaria. The second influence was that of changes which were taking place in African one-party states and autocratic military regimes. Finally came the example of the few African multy-party states like Botswana and Mauritius which proved that development, stability and democracy could go together in a multiparty scenario. ${ }^{16}$ These states had been there all the time, of course, but it was only when things were falling apart that recalcitrant mono-partyists thought they were worthwhile examples to study and copy.

There were many internal influences, but five came quickly to the fore: Firstly, Tanzania had been buffeted throughout the 1980's by severe economic problems which had forced upon the state the acceptance of Economic Recovery Programmes, which had in their turn resulted in demands for the opening up of access to political power more broadly. Secondly, the very open constitutional debate of 1983 revealed very grave weaknesses of the constitution and brought out into the open for the first time the debate on the merits and demerits of a three-governments-scenario for the union. ${ }^{17}$

Ex-President J. K. Nyerere who remained as Chairman of the ruling party, the Chama Cha Mapinduzi (CCM), toured the country in 1986 and 1987 do "dynamise" the party. What he

15

16

Nyalali Commission Report (supra note 1), Vol. 1, paras. 183-212.

17 Ibid.

Ibid. 
saw shocked him because as president he had been shielded from the rot. He realised how far away from the people the CCM had gone and how complacement the leadership had become.

Fourthly, the country was jolted by the speeches of the personification of one-partyism himself, Mwalimu Nyerere. These were and address to newspaper people in Dar es Salaam in February 1990 and a speech made in Mwanza in May 1990 while opening a congress of the CCM Youth. The theme that came out of those speeches was that if Tanzanians wanted to decide to continue with the one party system in the 1990s, they also had to come up with reasons of the 1990s and not those of the $1960 \mathrm{~s}^{18}$

Finally one has to mention the efforts of human rights activists in Tanzania beginning with the year $1984 .{ }^{19}$ It should be stressed here also that this yearning for democracy was very widespread among the general populace in Tanzania. The members of the Nyalali Commission, in the numerous public meetings and from many other sources, found many views coinciding between advocates of multiparty politics and one-party politics as far as democracy and openness were concerned. These were as follows: ${ }^{20}$

(a) There should be changes in the political system by either reforming it or scrapping it in order to either democratise it or usher democracy in.

(b) All sides agreed that they wanted peace, unity and understanding between all Tanzanians.

(c) In their desire to expand democracy, both sides advocated the importance of separating party from government business and giving civil organisations more autonomy.

(d) Both sides decried the 'Yes' or 'No' system in presidential elections and advocated the fielding of more than one candidate.

(e) They found party supremacy wanting and advocated parliamentary supremacy instead.

(f) They advocated the scrapping of "The Kofia-Mbili" system at all levels, i.e. one person holding two jobs, one of which should have been structurally answerable to the other.

(g) Both sides wanted leaders to be answerable to the people and to be nearer to them.

(h) They deplored the custom of leaders staying too long in power, enriching themselves through their offices, and protecting each other. It was clear to all that these leaders had no longer any mandate because they did not report back and could not be removed.

(i) Both sides insisted on the implementation of a citizen's right to elect and to be elected to leadership positions. 
(j) Both sides condemned the situation where citizens are forced to buy essential services or purchase their constitutional rights, e.g. medical treatment, educational service and administration of justice.

(k) Finally, both sides complained bitterly about the fact that peasants were not being paid on time or not at all for their crops. They were being issued promisory notes in lieu of cash. These notes could not, unfortunately, be translated into goods or services. Peasants could not, for example, pay taxes using these promisory notes. The state wanted cash!

The commission surmised that these eleven points pointed clearly to a lack of true democracy and accountability. True democracy, the commission noted, consisted of four essentials, namely respect for the Rule of Law, respect for human rights, periodic free and fair elections for leadership and policies, and freedom of information through a free mass media. $^{21}$

In many ways, however, the views of the people interviewed by the commission went beyond the concept of democracy generally held by many people: democracy as a form of state with parliamentarism which involves the institutionalisation of majority rule, as its most well-known form. The populace seemed to be articulating a more advanced form of democracy: political equality as the foundation of decision-making. "Kofia Mbili" is obviously against that equality as is the conflation of executive and law making.

\section{Proposals of the Commission and Government Response}

The Nyalali Commission made specific recommendations concerning the transitional period. These recommendations dealt with the dismantling of structures associated with the one party state, the state party as it had become, replacing those with new ones of a multi-party state, and the establishment of an environment conducive to multi-party democracy. Of the 26 specific recommendations made, about $50 \%$ had been partially or fully carried out by December $1992 .^{22}$

Five of the specific recommendations which were left out are very crucial in the shortterm. These are:

(a) a campaign or programme to educate or inform the people about the principles of multi-party democracy under which people;

(b) the introduction of teaching in schools of subjects on the constitution of Tanzania and on human rights;

21

22

Ibid., para. 355 .

Ibid. 
(c) the enhancement of academic freedom;

(d) the enhancement of the free flow of information and encouragement of the growth of a free press; and

(e) the abolition or amendment of oppressive laws. ${ }^{23}$

Recommendations (a) to (d) touch on education in a way which may seem to stress the point that democracy is a matter of attitudes and if people are educated enough, they will acquire those attitudes. Just as we pointed out above about tolerance, democracy has to be struggled for because there are interests involved. In this connection, several questions arise: Who will educate whom? Why will he/she educate? By what right? What will be the context of the education? Can an interested party be expected to education against his own interests?

The other area which needed examination in connection with education was which development preceded which: education for democracy or the democratisation of educational institutions and organisations first? Obviously, an undemocratic Ministry of Information cannot encourage the growth of a free press, nor can an undemocratically organised and run university be expected to help enhance academic freedom and least of all an undemocratic state.

The twenty-six specific recommendations should, however, be regarded as short-run recommendations and very many of the rest as long-run recommendations. The Nyalali Commission made 114 recommendations which, seen together, in fact all deal with the transition to multiparty democracy. ${ }^{24}$ The whole commission's work provides a base for careful study and debate. It shouldn't be allowed to gather dust on bureaucrats' shelves or desks.

In British administrative tradition, commission reports are usually followed by a white paper which is the government's reaction to the recommendation of a commission. Tanzania which follows that tradition has often produced white papers. In the case of the Nyalali Commission, no white paper has been produced to date to show clearly which of the recommendations were accepted fully or partially, which rejected fully or partially, nad why! So much of the people's time was taken to collect views which were deliberated on to lead to the recommendations that it would be a great courtesy to them to produce the white paper, and it would be a great step in the direction of transparency in the transition.

However, as the Presidential Commission was not a referendum whose results would have been binding on the government, white paper or no white paper, people can only manage

23

24

Ibid.

Ibid., paras. 650-709, 711-716. 
to move the government to act on the recommendations and other things it is silent on by applying pressure. It would seem very naive to expect government to apply recommendations which may be against entrenched interests or practices within the ruling party or the state.

Thirdly, the recommendation to set up a constitutional Commission and later call a Constituent Assembly as recommended in the Commission's Report ${ }^{25}$ is still valid today as it was when it was made in November 1991. The government has been amending the constitution haphazardly and in an ad hoc manner. Since a constitution is supposed to crystallize what direction generally a nation takes, the principles of the constitution should be truly national, and not partisan, and have as broad acceptance as possible. That can best be done by as broadly representative a body as possible. Efforts should be made to avoid patching the present constitution because, as the saying goes, the patches become the weakest link.

Fourthly, in order to create an enabling environment in which multipartyism could grow, the commission recommended the repeal or amendment of forty laws which it considered to be oppressive or restrictive in a democracy. ${ }^{26}$ Many of these laws were inherited from the colonial era. Others were added later. As pointed out earlier, colonialism was not a school in democracy; it was a school in authoritarianism, the instruments of which have no place in a democracy.

One way of handling the forty-plus laws would be to resort to the courts, since a state does not reform itself of its own volition; it has to be forced to reform. This would need an awakened citizenry which is ready to litigate. It would also require a judiciary that is not only very sure of its security of tenure, but is also free of pro-state attitudes it may still be carrying in its baggage as a result of thirty years of one-party authoritarianism which affected the courts fairly negatively.

History has taught us that the lack of a conducive atmosphere stymies democracy and induces fear in spite of all goodwill, as the following example illustrates. In February 1966, former President Julius Nyerere exhorted the people of Mafia Island in the Indian Ocean to overcome their fear of authority and be ready to press for their rights against leaders with the following words:

"This is your country. We tell you everyday that this is your country and that you have freedom of speech. If you do not accept responsibility for this country I shall claim ownerhsip of it. Any country must be looked after by people. If you do not like to 
accept the responsibility of looking after this country, I shall get a few clever people and together we will declare this country to be our property. ... If we do not remove fear from our people and if you do not abolish the two classes of masters and servants from our society, clever people will emerge from among us to take the place of the Europeans, Indians and Arabs. These clever people will continue to exploit our fear for their own benefit. And we leaders can become the clever people. ... This is going to happen if you do not remove fear from your minds. You will even lose your property. Suddenly you will discover that your Area Commissioner has a farm of 3,000 acres. You will be surprised to hear that even Julius has a 30,000 acre farm." ${ }^{27}$

The speech is quoted at length because it harps on fear and the overcoming of fear. The question arises, however, how the Mafia Islanders, or any other Tanzanians for that matter, could overcome fear and express themselves freely, when there were so many laws to shut them up quickly. Where were the institutions through which to shout? Was the tradition to shout there, and even if it was there, was it kept alive? The simple fact is that there was no institutional set-up to do this, and fear could not be removed by fiat or diktat. There may be less fear in the 1990s, but with oppressive or restrictive laws which can still be sued, one can hardly be surprised that many people still look over their shoulders when making political comments. ${ }^{28}$

Fifthly, there is an urgent need in the transitional period to cultivate a new political culture of tolerance of ideas which one may not agree with, of argumentation leading to conviction or failure to convince instead of forcing one's ideas through, and of persuasion instead of abuse. ${ }^{29}$ As noted at the beginning, colonialism did not bequeath this culture, and the thirty years of one-party rule did not cultivate it either. A democratic political culture has to be cultivated by everybody, including first and foremost CCM leaders who have to begin by shedding the idea that the one-party era is over and hose authoritarian way of acting had become a way of life. The people have to struggle to see to it that tolerance is won.

The Nyalali Commission did recommend that a special body be set up to oversee the transition programme. ${ }^{30}$ The work of the body would have included education for everybody in the political culture of "kupingana bila kupigana", the inculcation in students and pupils of ideas on the constitution and Human Rights, and the enhancement of academic

J.K. Nyerere, Freedom and Socialism, OUP (1969), pp. 139-141. The 'Julius' referred to is Nyerere.

The Prime Minister Mr. J.S. Malecela in a speech at the Extraordinary CCM National Conference, Feb. 17-18, 1992; DSM urged Regional and District Commissioners to use their powers against what he called "trouble makers".

Nyalali Commission Report (supra note 1), Vol. 1, himself.

Ibid., para. 709. 
freedom. ${ }^{31}$ One very good way to teach about the supremacy of the constitution and the sacredness of human rights would be to see that even top leaders violating them are punished.

The ruling party in Tanzania (CCM) arrogated to itself the monopoly of transmitting the political culture mentioned above. But besides the numerous admonitions to the opposition by the CCM top leaders not to use insults against the CCM leadership, nothing positive has been set in motion. ${ }^{32}$ There is need to go positively about the issue. One method would have been, for example, to call a meeting of all concerned parties who would agree on the rules of the game defining what would, for example, constitute an "insult". By arrogating to itself alone the management of the transition, the CCM acts in the field as one of the players who doubles also as referee and linesman.

Sixthly, the news media have a very important role to play in the transition. Some of the newspapers were the first to tackle so-called "sensitive issues" long before one talked of democracy. ${ }^{33}$ But they all have still a lot to learn. For example, a radio programme beamed on Saturdays and repeated on Sundays over Radio Tanzania Dar es Salaam sounded like police interrogation in the first few months of its operation. ${ }^{34}$ In a country where there is no television, and radio is the only reliable means to reach all people, radio should be independent of government. In addition, a two track media would seem to be the ideal to work for in a democracy. Media persons and the people themselves should look for ways of making the people reach the leaders, centers and cities, since they have as much right to address the leaders as the leaders have arrogated to themselves the right to talk down to the people.

Seven, the Commission recommended the strengthening of people's organisation by making the people, especially those in villages, recognise their rights. ${ }^{35}$ This applies especially to cooperatives and trade unions. More headway regarding democracy and people's control has been made in the institutional framework of the cooperative unions. ${ }^{36}$ They remain weak, however, with respect to their financial bases, and the IMF inspired interest rates which were imposed to restrict borrowing have not been of much help. The people are realising that the process should be a self-strengthening one:

31

32

33

34

35

36

Ibid., para. 715 (i), (vi) and (vii).

Statement by J.S. Malecela, Prime Minister, R.M. Kawawa, then Depucy CCM Chairman, and Horace Kolimba, CCM Secretary General, on numerous occasions heard over the radio by the author.

Examples are Jimmy Mdoe's 'Fahari' or 'The Family Mirror'.

Radio Tanzania Dar es Salaam, Saturdays 14.00 Hour "Tuambie" (i.e. Tell us).

Nyalali Commission Report (supra note 1), Vol. 1, para. 715 (viii).

See the 1991 Law on Cooperatives. 
Peasants and workers, students and NGOs are not waiting to be organised, but are waking up and organising themselves.

As to the trade unions, however, the Nyalali Commission was of the opinion that the act which brought OTTU into existence needed to be amended. ${ }^{37}$ It thought that the law was undemocratic because it, for example, provided for a sole trade union and, in so doing, did away with the freedom to organise alternatively which is entrenched in the constitution of Tanzania. ${ }^{38}$ In 1992, problems arose with teachers who wanted to form their own organisation instead of the OTTU-inspired one. How ridiculous the situation could become may be surmised from the following example. In one school, the Chairman of the OTTUcreated Tanzania National Teachers' Union (TANTU) was the school's cook... not even the cookery teacher. ${ }^{39}$

It is indeed an indication of the pressures from below by the teachers and other interests and of the mismanagement of the transition that the government was already thinking of amending the OTTU law to do away with monopoly, and this only one year after its enactment. $^{40}$

Organisations of civil society are important in the short and long run because, whereas many of the political parties may be aspiring only to replace the ruling party, the CCM, and may find themselves reneging on their democratic promises, some of the civil organisations may remain the only organs through which the people's will can be expressed. We say some civil organisations because quite a number of them are undemocratic.

\section{Effecting the Transition: the Political Parties Act}

In the process of effecting the transition to multi-partyism, the Tanzanian parliament passed a law known as the Political Parties Act, 1992. The law set guidelines in and limits to the transition process. It legislated about the process of registration and deregistration of political parties, elections, independent candidates, financing of political parties and so on. Whereas the idea of controlling the transition is good, it would have been definitely better if there had been greater consensus in preparing laws governing the process, because acceptability and legitimacy would have been less of a problem. In the event, the law raises many questions and even goes against certain sections of the consti-

37

38

Nyalali Commission Report (supra note 1), Vol. III, p. 82.

Constitution of the United Republic of Tanzania, Govt. Printer DSM, p. 20.

39 Information obtained from the professional teachers' organisation offices (CHAKIWATA).

40

See, Statement by Mr. Mdamo, Commissioner for Labour, Uhuru, 10 November, 1992. 
tution. $^{41}$ First, there is the question of the automatic deregistration of provisionally registered parties after 180 days. ${ }^{42}$ This provision would seem to be in conflict with the constitutional guarantee of the right to associate and organise as can be found in paragraph 20 of the constitution of the United Republic of Tanzania. Furthermore, the period of 180 days or six months raises the question of what is so magical about it. It may even be discriminatory because the underlying assumption is that all applicants have equal financial sources and time when that is most probably not the case. Therefore, the provision favours the stronger who have control over larger funds, can field more workers and therefore meet the pre-full registration conditions faster. A way out could have been to provisionally register parties till such time as they reached the required number of founding members. But more fundamental is the the fact that, had these principles been debated nationally, there would have been less problems of acceptance.

Secondly, one should reconsider the requirement to have two hundred members in ten regions each, two of which must be from the Islands of Zanzibar, one being in Unguja and one in Pemba. ${ }^{43}$ This provision was taken from the Nyalali Commission Report without change. ${ }^{44}$ The Commission itself had furious debates regarding this recommendation because it made no sense to some commissioners to require a party aspiring to win seats in the Zanzibar House of Representatives or the Zanzibar presidency only to have members on the mainland in Tanganyika in, say, Kyela, Mbinga, Kondoa or Ngorongoro. In a way, the furiousness of the debate was a reflection of the need to reexamine the union question. This must be done under multi-partyism because too many new equations are bound to come up.

In fact, in view of the commission's own recommendation to have a federal set-up with three governments instead of two, ${ }^{45}$ their recommendation about so-called pan-territorial parties remains contradictory and problematic. It seems that the commission was recommending against and the Parliament agreeing to legislate against the emergence of a strong Zanzibar-based party which would challenge the incumbent leadership. ${ }^{46}$ This would therefore seem to be a case of short-term political expedience rather than long-term nation vision. In the future, it may be found to be more practical to let parties float or sink on the basis of their popularity which would be measured at the polls.

41

42

43

44

45

46

That party seems to have been KAMAHURU, a vocal civil organisation led by Senior CCM leaders who had been thrown out of the CCM and were demanding a change of the constitution in 1991 to allow for the emergence of other parties. 
Thirdly, ideally, the Registrar of Political Parties' of fice should be autonomous. It should not be subject to some other office, especially a political one. The Political Parties Act makes the Registrar's decision subject to the agreement of the minister responsible for justice. ${ }^{47}$ A minister will usually come from a political party. Making him or her the final decision maker is in fact putting his/her party at an advantage vis-a-vis other parties.

Fourthly, some habits take long to die. The new law provided for and effected changes which fell into the old pattern of aiming laws at individuals or events. A section of the law $^{48}$ seems to have been aimed partly at Mr. Joseph K. Nyerere, younger brother of exPresident Julius K. Nyerere, and partly at the feared resurrection of old parties in Zanzibar. Joseph Nyerere had publicly declared his intention to revive the Tanganyikan predecessor of the CCM, the Tanganyika African National Union (TANU). This move would have been quite a challenge to the CCM. The other habit is democracy by legislation. The ruling party, CCM, got automatic registration. ${ }^{49}$

One can sympathise with the logic of wanting to provide continuity and trying to avoid the necessity of having to organise a transitional government. But, since the CCM fulfilled all registration conditions at both stages, it would have been an indication of the start of a new era if it had subjected itself to the process like other parties. As it is, the CCM was put in a different league altogether. By providing for registration within the law, it was put beyond the reach of the Registrar of Political Parties. He cannot in fact discipline it, as this can be done only by parliament which legislated it into being. ${ }^{50}$

Finally, a few words on independent candidates. The new law bars private candidates from standing for presidential or parliamentary elections. ${ }^{51}$ The genesis of this ban seems to be some chance remark by a Commissioner in the Nyalali Commission. A scenario was elaborated in which, in the event of the Zanzibar part of Tanzania making it difficult to register a Zanzibar-based party, the unregistered party could put up many independent candidates. If these won the majority in the House of Representatives and proceeded to agree on a platform, they could theoretically form a government which would in fact be the government of the unregistered party. ${ }^{52}$

Political Parties Act, 1992, Sections 15 (2) and 18.

Ibid., Section 12 (1).

Ibid., Section 7 (2).

At a rally in Zanzibar addressed by the Zanzibar President who is at the same time the Vice-Chairman of the CCM for the isles, old Afri-Shirazi Party (ASP) symbols (mapakacha) were used against what the new law provided for. The registrar said nothing!

Elections (Amendment) Act, 1992. Local Authorities (Elections) (Amendment) Act, 1992, Section 9.

The scenario was very real - see footnote 46 . 
The problem would not have been a Zanzibar problem only. One can imagine how many of the CCM old guards would have fallen if the CCM, as it was used to do, forced an unpopular candidate on a constituency and the constituents supported an independent candidate who would of course win. One can imagine a field day for independents!

The ban raises a very serious constitutional problem. Article twenty of the constitution provides for freedom of association as a right. Section 2 of this article protects citizens from being compelled to belong to any association. ${ }^{53}$ Article twenty-one of the constitution provides a right for participation in national public affairs. ${ }^{54}$ The ban against private candidates contravenes Article 20 because it forces one to be a member of an association if one wants to exercise one's right to participate in national public affairs. In this instance the ban forces people to belong to political parties. Beyond the question of the constitution, there is the practical question of what should be the site of politics. The ban clearly expresses the position that only political parties are sites of politics, as any other organisation would not have the right to express or act in a political way. This takes us back to the authoritarian conception of politics.

A committee set up under the chairmanship of Mark Bomani to look into and recommend measures concerning the powers of the president, vice-president, prime minister, and of parliament recommended that, except for the presidency, all other offices should be contested by any qualified candidate including a private one. ${ }^{55}$ It seems to have lifted the presidency into a category of its own which should not be sullied by private candidates, since no other reasons were given for this exclusion. What was needed, however, was not to bar independent candidates but to require them, once elected, to remain independent, otherwise they lose their seats.

\section{The Financing of Political Parties}

The Nyalali Commission was aware of the dangers in a multiparty context of financiers from outside of the country giving money to political parties and placing themselves in a position of pushing their policies and programmes, to the extent of having the country run as a puppet. ${ }^{56}$ The commission recommended that parties which manage to get representative into parliament should obtain a state subvention proportional to their representative

53 54

55 Govt. of Tanzania, "Taarifa y a Kamati y a Wataalamu Kuhusu Uchaguzi wa Rais wa Muungano na

Masuala Mbalimbali yanayoambatana Nayo", DSM (1992), para. 134.

56

The Constitution of the United Republic of Tanzania, 1977, op. cit., Article 20.

bid., Article 21.

Nyalali Commission Report (supra note 1), Vol. 1, para. 449. 
and/or those parties which manage to obtain a certain minimum percentage of votes in a general election but fail to place a member of parliament into the house. ${ }^{57}$ This was recommended so as to minimize the attraction for parties to solicit external finance.

The commission was not unaware of the fact that even the CCM used to obtain aid from sister parties and governments abroad to run its affairs. ${ }^{58}$ Their library in Dodoma was built up by money from the Friedrich-Ebert-Stiftung (FES), a foundation of the German Social Democratic Party (SPD); part of Kivukoni College was built with initial seed money from the Konrad-Adenauer-Stiftung (KAS), a foundation of the conservative Christian Democratic Party of Germany (CDU), to be later taken up by the FES. The Chimwaga Conference Centre in Dodoma which was originally supposed to be the national headquarters of the CCM cum parliament building was put up partly with North Korean assistance. $^{59}$

The commission was aware also of the fact that a lot of CCM funds came from state coffers and a lot of property both movable and immovable had been acquired through collections from all nationals irrespective of their being members of the CCM or not, or through the use of their labour. It recommended therefore that an assessment be made of members' contributions as opposed to those of non-members and a decision be made whether they revert to the government or remain CCM property. ${ }^{60}$ Other recommendations concerned a stop to deductions made from members' salaries and the subsidizing of CCM officials. 61

The recommendation that "CCM property" which is proved to be "public property" revert to the government seems to be as valid today as when it was made. The CCM leadership has made a decision on this in favour of itself. Property which could no longer be completed without state subvention or people's contributions was "given" to the government. ${ }^{62}$ Regarding the rest, a law was quickly enacted making the CCM the sole successor of all properties and assets. ${ }^{63}$ If the recommendations of the Nyalali Commission had been followed, one use that the proceeds from the rental of property could have been

57

58

59 Informatic

60

61

63

Ibid., para. 462 (vi).

Ibid., para. 449.

Nyalali Commission Report (supra note 1), Vol. 1, para. 712 (xiv) and para. 716 (2).

Ibid., para. 715 (iv) and (v) and para. 716 (2).

Constitutional (Consequential, Transitional and Temporary Provisions) Act, 1992, Section 14 (1), (2) and (3). 
put to would have been to finance political parties according to a formula which would have been agreed upon. In the event, and after the winding down of the overblown CCM bureaucracy, enormous of fice space was released, and it is being rented out by the CCM with the proceeds used to run its affairs; "CCM" cars are being used to transport people as public vehicles. ${ }^{64}$ This would seem to be a very unfortunate waste of a golden opportunity to solve partially the problem of financing of political parties, as well as patently unjust to non-CCM forced "contributors".

Other measures weill have to be taken to control both internal and external finance. Many countries require parties to declare grants or donations to them exceeding a certain amount and to keep clean accounts. It is, however, difficult to police as again experience from other countries shows. ${ }^{65}$

\section{By Way of Conclusion}

It was noted earlier that TANU systematically intimidated other parties out of existence in 1963 and finally legislated itself as the sole party. The sole party became so all pervasive and many of the laws of the land to a large extent so undemocratic that the government of the land and the party bureaucracy became all powerful. The National Assembly became weak, accountability by leaders to the people became history and justice depended on the goodwill of the top leadership and not on institutional checks and balances. Indeed, exPresident Julius Nyerere in a BBC Interview once commented: "I have enough power to become a dictator". 66

The chance Tanzania has now is a good one to usher democracy and accountability. But the chance can be wasted if certain people try to cling to power or refuse to have a clean fight as recommended by the Nyalali Commission. ${ }^{67}$ A new political culture must be cultivated, and it cannot be cultivated by one party dictating to others but by consensus. In Namibia, before the UN supervised elections, all parties met and agreed on a code of conduct. This was in a country which had gone through many years of a shooting war. In

The author saw this dome in the Rukwa Region where offices in the regional CCM office and the Nkansi District office in Namanyere had been rented out and the district CCM Land Cruiser with "CCM" registration plied between Namanyere and Kirando, a port on Lake Tanganyika. One room in the district CCM office had been turned into a bottle store run by a former CCM official, others had been turned into part of a guest house. The CCM retained only three rooms out of over 14 . Mauritius, a country the author visited in 1991, is plagued by non-declaration of donations.

66 J.K. Nyerere, British Broadcasting Corporation interview quoted by C.M. Peter, in VRÜ, 2nd 67 Quartal, 1987, p. 239

67 Nyalali Commission Report (supra note 1), Vol. 1, para. 462 (i) and (ii) and para 450. 
Tanzania where peace has reigned for many, many years, it should be a simpler exercise. Indeed, it takes at least two parties to reach an agreement. "Kupingana bila kupigana" and "kukosoana bila kutukanana wala kukashifiana" 68 will require the proverbial two to agree on the modalities.

68 Nyalali Commission terminology on the proposed new political culture. Ibid. The beautiful play on words translated means: "To differ without quarelling and to point out shortcomings and mistakes without reverting to insults and scandal mongering". 
Obstacles related to context are due to

a) the African political system which is characterized by the following factors:

- the authoritarianism of the African regimes prevents defendants from suing the administrative authorities for fear of retaliation so that they rather seek to settle conflicts through negociation.

- the justice system, subservient to the political power and the power of money, thus losing all credibility in the eyes of the African populations because of its partiality and vulnerability.

- the ineffectiveness of the institutions, as a result of the adoption by the African countries of western-style "modern" institutions, confining them to the museum of legal institutions.

b) Misappreciation of the foreign law transplanted to Africa takes on a double aspect:

- ignorance of the above-mentioned law by those Africans who are expected not to ignore it by virtue of the maxim "nemo legem ignorare censetur".

- refusal by the same persons to resort to state courts as the western justice concept is totally different from that of Africa based on the idea of conciliation.

Finally, and in order to cross this legal Rubicon, it seems essential to move towards a new symbiotic law capable of meeting both the requirements of economic development and the deep aspirations of the African populations.

\title{
The Transition to Multiparty Democracy in Tanzania: Some History and Missed Opportunities
}

\author{
By K. I. Tambila
}

After twenty-eight years of one-party rule, the constitution of Tanzania was amended in July 1992 to allow other parties to be formed. The amendment was made after a countrywide study of the mood and wishes of the Tanzanian people was undertaken by a Presidential Commission headed by the country's Chief Justice, Francis Nyalali.

Tanzania went through a short period of multi-party politics in the pre-independence period and an even shorter phase of two years after independence. Because of the colonial heritage which was undemocratic and also because of a widely accepted developmentalist ideology, among many other reasons, authoritarianism was easily resorted to by the nationalist leaders who inherited the colonial state and its apparatus. Developmentalism was also widely accepted by the Tanzanian populace who wanted quick and visible development denied it by the British and the Germans before them. In due course the ideology resulted in stifling the very development which was being pursued and created a 
group of people who, because they had benefited from running the party and state, became accountable only to themselves; they were unresponsive to the wishes of the people.

The Nyalali Commission, as it has come to be known, made over one hundred and fourteen recommendations to the government to guide the transition and to facilitate the functioning of a widely accepted democratic regime. Some recommendations were taken up quickly, but very many others were not and, by deciding not to issue a White Pater on the report, the government has purposely tried to stymie discussion on the recommendations. The paper argues that it is understandable that the state would like to avoid chaos by managing the transition tightly. However, this management seems to be influenced too much by partisan interests, to the extent that a very good opportunity is being missed to put a broadly-accepted and working democratic regime in place.

\section{Human Rights and the Widow's Material Security: The Case of the "Intestate" Ghanaian Widow}

\section{By David M. Dzidzornu}

Essentially, the predominant customary system of inheritance in Ghana disentitles a widow to any viable or appreciable interest in her intestate husband's estate. This is so notwithstanding that the wife (or wives) in question would have made undeniably substantial contributions to the property ascribed to the husband as his self-acquired estate. To a large extent, the Ghanaian widow's (non-)inheritance situation reflects the experience of wives in many other African societies. In human rights terms, there exist global and African (regional) principles that philosophically censure this state of affairs. The influence of those principles on the phenomenon is, however, largely notional. Thus, the piecemeal changes that have been made to Ghana's inheritance law regime, eventually culminating in the passage of the Intestate Succession Law, 1985 (PNDC Law 111), have been impelled by national agitation against an inequitable customary inheritance institution that has for decades lagged behind socio-economic changes in the country. With minimal emendations in procedure and substance, the legislative regime introduced by Ghana's Law 111 should be a fair balance between the legitimate interests of families in the fortunes of their sons, and the prior obligations of these sons to ensure the material welfare of their widows (and dependent children). 